\title{
PARASITOIDS OF SPARGANOTHIS PILLERIANA (DEN. ET SCHIFF.) (LEPIDOPTERA: TORTRICIDAE) IN SOUTHERN VINEYARDS OF ROMANIA
}

\author{
Daniela Bărbuceanu ${ }^{1 *}$, Mircea Bărbuceanu ${ }^{1}$, Ionel Andriescu ${ }^{2}$ \\ ${ }^{1}$ University of Piteşti, Faculty of Sciences, Physical Education and Informatics, Târgu din Vale St. 1, \\ 110040, Piteşti, Romania \\ ${ }^{2}$, ,Al. I. Cuza” University, Faculty of Biology, Copou Bd. 20A, Iaşi, Romania
}

Current Trends in

Natural Sciences

\begin{abstract}
Sparganothis pilleriana (Den. et Schiff.) is a microlepidopteran known in the vineyards of Western and Southern Romania, with small populations and of low economic importance. As a result of the rearing of grape leaf-roller larvae and pupae, 29 species belonging to the Hymenoptera and Diptera have been obtained as primary and secondary parasitoids. These species were collected from two vineyards located in the southern part of Romania, characterized by different climatic and chemical treatment conditions. Catolaccus ater (Ratzb.), Pediobius spp., Elasmus spp. and Eupelmus vesicularis (Retz.) were recorded as secondary parasitoids, while Brachymeria tibialis (Walk.), Dibrachys cavus (Walk.) and Elasmus viridiceps (Thoms.), as primary and secondary parasitoids. 35 host-parasitoid relationships have been recorded, many of them new to science. The contribution of these parasitoids to the reducing of grape leafroller populations was 20.77\%. The important contribution belongs to the Ichneumonidae family, for which the parasitization ratio was $8.29 \%$. B. tibialis (Walk.), Nemorilla maculosa (Meig.), Diadegma germanicum (Horst.) and Goniozus claripennis (Först.) are the most important components of this parasitoid complex. Four parasitoids species were obtained by rearing in laboratory as secondary parasitoids of G. claripennis (Först.): C. ater (Ratzb.), E. viridiceps (Thoms.), Elasmus spp., and E. vesicularis (Retz.).
\end{abstract}

Keywords: grape leaves-roller, parasitizing ratio, relationships.

\section{INTRODUCTION}

Sparganothis pilleriana (Den. et Schiff.), known as Pyrala in viticulture, is a polyphagous species which, since a long time ago, has caused significant damage in European vineyards. In the last half of the XX century, this species was a notable pest in the Champagne vineyards - France, Switzerland, Austria, Hungary and Spain (Russ, 1969; Saglio et al., 1977), and in Iran it represented, along with Eudemis, the main pest of vines (Zoebelein, 1966). Nowadays, Reineke and Thiéry (2016) consider Pyrala's area restricted to several local regions in France, Germany and Spain. It has one generation, and its peculiarity is that its biological cycle unfolds over two consecutive years, after a hibernal larval diapause of 7 to 9 months (Bovey, 1966; Galet, P., 1982). Decreasing the severity of its attack through developing a number of efficient control methods, involves knowing the role played by the complex of parasitoids that act on the pest. To that effect, the first studies are conducted in France, in 1842, by Audouin (quoted in Voukassovitch, 1924), who indicated 15 species of Hymenoptera, and a dipterous-tachinide as parasitoids. Voukassovitch 
(1924) continued the study of parasitoids on S. pilleriana (Den. et Schiff.) in France, and identified 25 species of Hymenoptera and 5 species of Tachinidae as primary and secondary parasitoids. Thompson (1957) published a list of 38 parasitoid species cited in the literature of his time, of which 5 Braconidae species, 12 Ichneumonidae species, one Betylidae species, one Chalcididae species, 7 Pteromalidae species, one Eulophydae species, one Thorymidae species, one Trichogrammatidae species and 9 Tachinidae species.

During the last half of the XX century, there have been few studies concerning this topic (Pykhova, 1968; Alfaro-Moreno, 1966; Schirra and Louis, 1995, etc.). The vast wine-growing areas of France maintain the interest for the natural enemies, in such a way that, at the beginning of the XXI century, new species of parasitoids were highlighted and data from the literature on Pyrala's parasitoids were systematized (Thiéry et al., 2001; Thiéry, 2008; Thiéry et al., 2011; Martinez, 2012; Villemant et al., 2012).

The grape leaf-roller is also known as a pest in the vineyards of Western Romania since the end of the XIX century, as it appears from the works of Heves (1884) and Jablonowski (1900) (quoted in Predescu, 1971). In the last half of the XX century, important populations of the species were mentioned in several vineyards in the Western Romania (Predescu, 1967, 1971), and were as well reported in the north-eastern vineyards, but without economic importance (Luca, 1981), and at the beginning of the XXI century there were highlighted in the vineyards in the south of the country (Bărbuceanu, 2005).

Regarding natural enemies, five species of parasitoids have been identified in Romania, species which control the population of the pest in the vineyards located in western Romania: Itoplectis maculator (F.), Cremastus dalmatinus Strobl., Diadegma fenestrale (Holmgr.), Exochus consimilis Holmgr., and Nemorilla floralis (Fall.). The species D. fenestrale (Holmgr.) was noted, with a larval parasitism rate that varied between 6-15\% (Predescu, 1971).

In our contribution, the species of parasitoids are presented, which have been obtained through rearing larvae and pupae of $S$. pilleriana (Den. et Schiff.) collected in two vineyards in Southern Romania, as well as and their importance in controlling the pest's populations.

Our study brings important contributions to the knowledge of the parasitoid complex in question, almost a century after the study of Voukassovitch (1924) in vineyards of France.

\section{MATERIALS AND METHODS}

The observations were carried out in two vineyards in Southern Romania, namely Ştefăneşti and Dăbuleni. The vineyard of Ştefăneşti, located in the central southern region of the Wallachian hills, and characterized by a rather wet and cool climate until the year 2000, later warmer, presented a small S. pilleriana (Den. et Schiff.) population, found on a third of the 3 ha surface of the vineyard area. In the vineyard of the Research - Development Center for Field Crops on Sandy Soils Dabuleni, located in Southern Oltenia near the Danube, with a climate characterized by Mediterranean influences, the $S$. pilleriana population was well developed on a 2 ha surface. The vineyards were different given the regimen of the chemical treatments carried out in areas damaged by this pest over the period of observations. Thus, in Dăbuleni, there were no systematic insecticide treatments till 2001, but over the first part of June 2002, when the flowering time ended, a treatment was applied against the larvae of the leaf rolling tortrix. In the Ştefăneşti vineyard, up to the year 2000 systematic chemical treatments were conducted against the larvae of the grape moths, which also fought the larvae of $S$. pilleriana (Den. et Schiff.), present in the vineyard during the same period as those of the first generation; subsequently, no more insecticide treatments were done. 
The samplings were done over the period of activity of the host, i.e. May to July, in the years 1998, 2000-2003, for the variety Fetească regală, in Ştefănești, and 2000-2002, for the variety Roşioara, in Dăbuleni. The 1,170 larvae and pupae collected were reared in laboratory conditions, after being isolated in glass containers in order to retain the possible parasitoids. The larvae were fed, daily, with vine leaves. Out of the samples, 243 were parasitized.

For a comparative study, a new series of samples was wanted to be collected ten years after the initiation of this study, but real estate interests in Stefaneşti caused the removal of the vineyards where the observations were made, so that currently the wine-growing area from Stefaneşti is drastically diminished and made our approach impossible.

Also, within the Research - Development Center for Field Crops on Sandy Soils Dăbuleni, the vineyard where the observations took place was removed, together with the almost 650 ha of vineyards, currently only on an area of 13.78 ha being again cultivated the varieties Fetească neagră, Riesling Italian, Roşioara.

\section{RESULTS AND DISCUSSIONS}

\section{The parasitoid complex of Sparganothis pilleriana (Den. et Schiff.)}

In Ştefăneşti and Dăbuleni vineyards, populations of $S$. pilleriana (Den. et Schiff.) were controlled by 29 species of primary parasitoids and hyperparasitoids in the orders Hymenoptera and Diptera.

The following species were obtained: Itoplectis maculator (Fabricius 1775), Pimpla rufipes (Mil.) (syn. instigator), Phytodietus spp., Phytodietus ornatus Desvignes 1856, Phytodietus polyzonias (Förster 1771), Diadegma contractum (Brischke 1880), D. germanicum (Horstmann 1973), D. holopygum (Thomson 1887), D. laricinellum (Strobl. 1904), D. longicaudatum (Horstmann 1969), D. tenuipes (Thomson 1887), Exochus consimilis Holmgren 1858, and Mesochorus (Stictopisthus) bilineatus Thomson 1886 (Ichneumonidae); Microgaster globata (Linnaeus 1758) and Apanteles lenea Nixon 1976 (Braconidae); Goniozus claripennis (Förster 1851) (Bethylidae); Brachymeria tibialis (Walker 1834) (Chalcididae); Pteromalus spp., Cyclogastrella deplanata (Nees 1834), Dibrachys cavus (Walker 1835), Dibrachys spp. and Catolaccus ater (Ratzeburg, 1852) (Pteromalidae); Colpoclypeus florus (Walker 1839), and Pediobius spp. (Eulophidae); Elasmus viridiceps Thomson, 1878 and Elasmus spp. (Elasmidae); Eupelmus vesicularis (Retzius 1783) (Eupelmidae); Nemorilla maculosa (Meigen 1824), and Pseudoperichaeta nigrolineata (Walker 1853) (Tachinidae) (Fig. 1).

Moreover, D. laricinellum Strobl. was obtained as new species for Romania's fauna by the rearing of grape leaf-roller larvae, subsequently mentioned by Pisică (2005).

The nature of the host-parasitoid relationship and the degree of novelty are presented in Table 1 . Paull and Austin (2007) mention about 20 species of parasitoids of Epiphyas postvittana (Walker), a major pest of grapes in Australia and New Zealand.

In the period of our study, the parasitoids ensured a parasitizing ratio of $20.77 \%$ (Table 2), which denotes the important role of these insects in the conditions in which there is currently an expansion of the use of pesticides worldwide, with a drastic effect on entomophages (Desneux et al. 2007; Geiger et al., 2010).

These parasitoids are polyphagous or oligophagous species, most of them developing more than one generation per year, so that they are able to find alternative hosts for their development in the biotope in question. Also, some species have a wide spread, with a high ecological plasticity, such as the case of Pteromalid Dibrachys cavus (Moreau et al., 2010). 


\section{Current Trends in Natural Sciences}

Vol. 9, Issue 17, pp. 307-316, 2020

https://doi.org/10.47068/ctns.2020.v9i17.039

Current Trends in Natural Sciences (on-line)

ISSN: 2284-953X

Current Trends in Natural Sciences (CD-Rom)

ISSN: 2284-9521

ISSN-L: 2284-9521

ISSN-L: 2284-9521

Most of the primary parasitoids are larval (16), six species are pupal (P. rufipes (Mil.), B. tibialis (Walk.), Pteromalus spp., C. deplanata (Nees), Dibrachys spp., D. cavus (Walk.)), and three species are larval and/or larvo-pupal parasitoids (I. maculator (Fabr.), N. maculosa (Meig.) and P. nigrolineata (Walk.) (Table 1). The most efficient family in limiting the host populations belong to the Ichneumonidae family with 13 species and a parasitizing ratio of $8.29 \%$, followed by the Chalcididae and the Tachinidae, while the Braconidae and the Elasmidae families had a minor participation in primary parasitism: $0.51 \%$, and, respectively, $0.13 \%$ (Table 2). As far as the parasitizing ratios of the parasitoid species, the species B. tibialis (Walk.) can be singled out as the most important parasitoid, as its participation in reducing the host populations amounts to $3.59 \%$ (Fig. 2).

The role played by the hyperparasitoids of $S$. pilleriana (Den. et Schiff.) has been found to be of little significance (Table 3) (Bărbuceanu and Andriescu, 2012).

In Ştefăneşti, over the period 1998, 2000-2003 twenty-one species of primary parasitoids and hyperparasitoids were obtained, out of which 18 species of primary parasitoids, and 3 species of hyperparasitoids: C. ater (Ratzb.), Pediobius spp., and E. vesicularis (Retz.).

Following the order of significance in parasitizing the host, the species $N$. maculosa (Meig.), $C$. florus (Walk.) and B. tibialis (Walk.) can be singled out (Fig. 3).

In Dăbuleni, over the period 2000-2002, twenty species of primary parasitoids and hyperparasitoids were obtained, out of which 15 species as primary parasitoids, 3 species as primary and secondary parasitoids, i.e. B. tibialis (Walk.), E. viridiceps Thoms. and D. cavus (Walk.) (Fig. 3), 2 species as secondary parasitoids, i.e. C. ater (Ratzb.) and Elasmus spp.. A case of multiple parasitism was recorded in a larva of $S$. pilleriana (Den. et Schiff.), collected in the year 2002, realized by a female of C. florus (Walk.) and a female of E. viridiceps Thoms. (Bărbuceanu and Andriescu, 2010). Following the order of significance in parasitizing the host, the species B. tibialis (Walk.), G. claripennis (Först.), D. germanicum (Horst.) and N. maculosa (Meig.) can be singled out.

Out of the 29 species of primary parasitoids and hyperparasitoids, 11 species of primary parasitoids (Fig. 3) and the hyperparasitoid $C$. ater (Ratzb.) are common to these vineyards.

If we consider, in a comparative manner, the role of parasitoids in controlling the S. pilleriana (Den. et Schiff.) populations in Ştefăneşti and Dăbuleni, important differences can be found (Table 2).

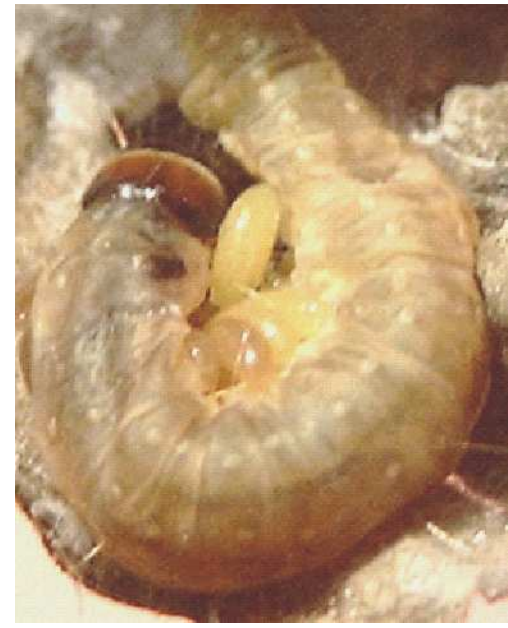

a

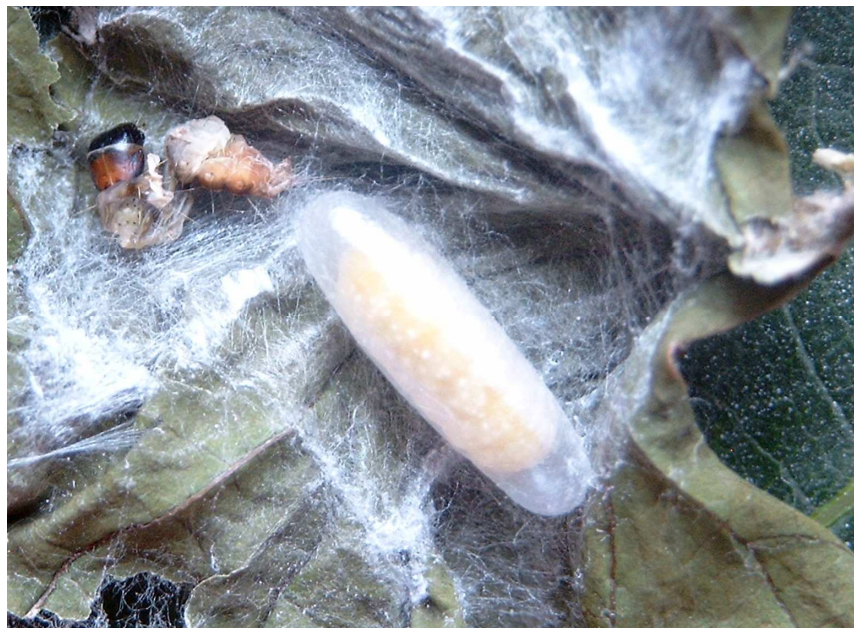

b

Figure 1. a. Sparganothis pilleriana caterpillar parasitized by Colpoclypeus florus larvae b. Phytodietus ornatus cocoon near the remains of S. pilleriana caterpillar 
Current Trends in Natural Sciences

Vol. 9, Issue 17, pp. 307-316, 2020

https://doi.org/10.47068/ctns.2020.v9i17.039

Current Trends in Natural Sciences (on-line)

ISSN: 2284-953X

Current Trends in Natural Sciences (CD-Rom)

ISSN: 2284-9521

ISSN-L: 2284-9521

ISSN-L: 2284-9521

Table 1. The host-parasitoid relationships

\begin{tabular}{|c|c|c|c|c|}
\hline No. & Host & Parasitoid & $\begin{array}{c}\text { Larval/ } \\
\text { Pupal/ } \\
\text { Larvo-pupal } \\
\end{array}$ & $\begin{array}{c}\text { relationship (novelty) } \\
\text { at the time of } \\
\text { research }\end{array}$ \\
\hline \multirow{25}{*}{1.} & \multirow{25}{*}{$\begin{array}{l}\text { LEPIDOPTERA } \\
\text { TORTRICIDAE } \\
\text { SPARGANOTHINAE } \\
\text { Sparganothis pilleriana } \\
\text { (Den. et Schiff.) }\end{array}$} & $\begin{array}{l}\text { ICHNEUMONIDAE } \\
\text { Itoplectis maculator (Fabricius 1775) }\end{array}$ & $\mathrm{L} / \mathrm{L}-\mathrm{P}$ & known \\
\hline & & Pimpla rufipes (Mil.)(syn. instigator) & $\mathrm{P}$ & New for Romania \\
\hline & & Phytodietus sp. & $\mathrm{L}$ & New for Romania \\
\hline & & Phytodietus ornatus Desvignes 1856 & $\mathrm{~L}$ & New to science \\
\hline & & Phytodietus polyzonias (Förster 1771) & $\mathrm{L}$ & New to science \\
\hline & & Diadegma contractum (Brischke 1880) & $\mathrm{L}$ & New to science \\
\hline & & Diadegma germanicum (Horstmann 1973) & $\mathrm{L}$ & New to science \\
\hline & & Diadegma holopygum (Thomson 1887) & $\mathrm{L}$ & New to science \\
\hline & & Diadegma laricinellum (Strobl. 1904) & $\mathrm{L}$ & New to science \\
\hline & & Diadegma longicaudatum (Horstmann 1969) & $\mathrm{L}$ & New to science \\
\hline & & Diadegma tenuipes (Thomson 1887) & $\mathrm{L}$ & New to science \\
\hline & & Exochus consimilis Holmgren 1858 & $\mathrm{~L}$ & known \\
\hline & & $\begin{array}{l}\text { Mesochorus (Stictopisthus) bilineatus Thomson } \\
1886\end{array}$ & $\mathrm{~L}$ & New to science \\
\hline & & $\begin{array}{l}\text { BRACONIDAE } \\
\text { Microgaster globata (Linnaeus 1758) }\end{array}$ & $\mathrm{L}$ & New to science \\
\hline & & Apanteles lenea Nixon 1976 & $\mathrm{~L}$ & New to science \\
\hline & & $\begin{array}{l}\text { BETHYLIDAE } \\
\text { Goniozus claripennis (Förster 1851) }\end{array}$ & $\mathrm{L}$ & New for Romania \\
\hline & & $\begin{array}{l}\text { CHALCIDIDAE } \\
\text { Brachymeria tibialis (Walker 1834) }\end{array}$ & $\mathrm{P}$ & New for Romania \\
\hline & & $\begin{array}{l}\text { PTEROMALIDAE } \\
\text { Pteromalus spp. }\end{array}$ & $\mathrm{P}$ & New for Romania \\
\hline & & Cyclogastrella deplanata (Nees 1834) & $\mathrm{P}$ & New for Romania \\
\hline & & Dibrachys cavus (Walker 1835) & $\mathrm{P}$ & New for Romania \\
\hline & & Dibrachys spp. & $\mathrm{P}$ & New for Romania \\
\hline & & $\begin{array}{l}\text { EULOPHIDAE } \\
\text { Colpoclypeus florus (Walker 1839) }\end{array}$ & $\mathrm{L}$ & New for Romania \\
\hline & & $\begin{array}{l}\text { ELASMIDAE } \\
\text { Elasmus viridiceps Thomson, } 1878\end{array}$ & $\mathrm{~L}$ & New for Romania \\
\hline & & $\begin{array}{l}\text { TACHINIDAE } \\
\text { Nemorilla maculosa (Meigen 1824) }\end{array}$ & $\mathrm{L} / \mathrm{L}-\mathrm{P}$ & New for Romania \\
\hline & & Pseudoperichaeta nigrolineata (Walker 1853) & L/L-P & New for Romania \\
\hline 2. & $\begin{array}{l}\text { HYM: } \\
\text { ICHNEUMONIDAE } \\
\text { Diadegma } \text { spp. }\end{array}$ & $\begin{array}{l}\text { CHALCIDIDAE } \\
\text { Brachymeria tibialis (Walker 1834) }\end{array}$ & $\mathrm{P}$ & New to science \\
\hline \multirow[t]{2}{*}{3.} & \multirow[t]{2}{*}{ Ichneumonidae gen. spp. } & $\begin{array}{l}\text { PTEROMALIDAE } \\
\text { Dibrachys cavus (Walker 1835) }\end{array}$ & $\mathrm{P}$ & New for Romania \\
\hline & & Catolaccus ater (Ratzeburg, 1852) & $\mathrm{P}$ & New for Romania \\
\hline \multirow{4}{*}{4.} & \multirow{4}{*}{$\begin{array}{l}\text { BETHYLIDAE } \\
\text { Goniozus claripennis } \\
\text { (Förster 1851) }\end{array}$} & $\begin{array}{l}\text { PTEROMALIDAE } \\
\text { Catolaccus ater (Ratzeburg, 1852) }\end{array}$ & $\mathrm{P}$ & New for Romania \\
\hline & & $\begin{array}{l}\text { ELASMIDAE } \\
\text { Elasmus viridiceps Thomson, } 1878\end{array}$ & $\mathrm{~L}$ & New for Romania \\
\hline & & Elasmus spp. & $\mathrm{L}$ & New to science \\
\hline & & $\begin{array}{l}\text { EUPELMIDE } \\
\text { Eupelmus vesicularis (Retzius 1783) }\end{array}$ & $\mathrm{P}$ & New to science \\
\hline 5. & $\begin{array}{l}\text { CHALCIDIDAE } \\
\text { Brachymeria tibialis } \\
\text { (Walker 1834) }\end{array}$ & $\begin{array}{l}\text { PTEROMALIDAE } \\
\text { Catolaccus ater (Ratzeburg, 1852) }\end{array}$ & $\mathrm{P}$ & New for Romania \\
\hline \multirow{2}{*}{6.} & \multirow{2}{*}{$\begin{array}{l}\text { DIP: TACHINIDAE } \\
\text { Nemorilla maculosa } \\
\text { (Meigen 1824) }\end{array}$} & $\begin{array}{l}\text { PTEROMALIDAE } \\
\text { Catolaccus ater (Ratzeburg, 1852) }\end{array}$ & $\mathrm{P}$ & New to science \\
\hline & & $\begin{array}{l}\text { EULOPHIDAE } \\
\text { Pediobius sp. }\end{array}$ & $\mathrm{P}$ & New to science \\
\hline
\end{tabular}




\section{Current Trends in Natural Sciences}

Vol. 9, Issue 17, pp. 307-316, 2020

https://doi.org/10.47068/ctns.2020.v9i17.039

Current Trends in Natural Sciences (on-line) ISSN: 2284-953X

Current Trends in Natural Sciences (CD-Rom)

ISSN: 2284-9521

ISSN-L: 2284-9521

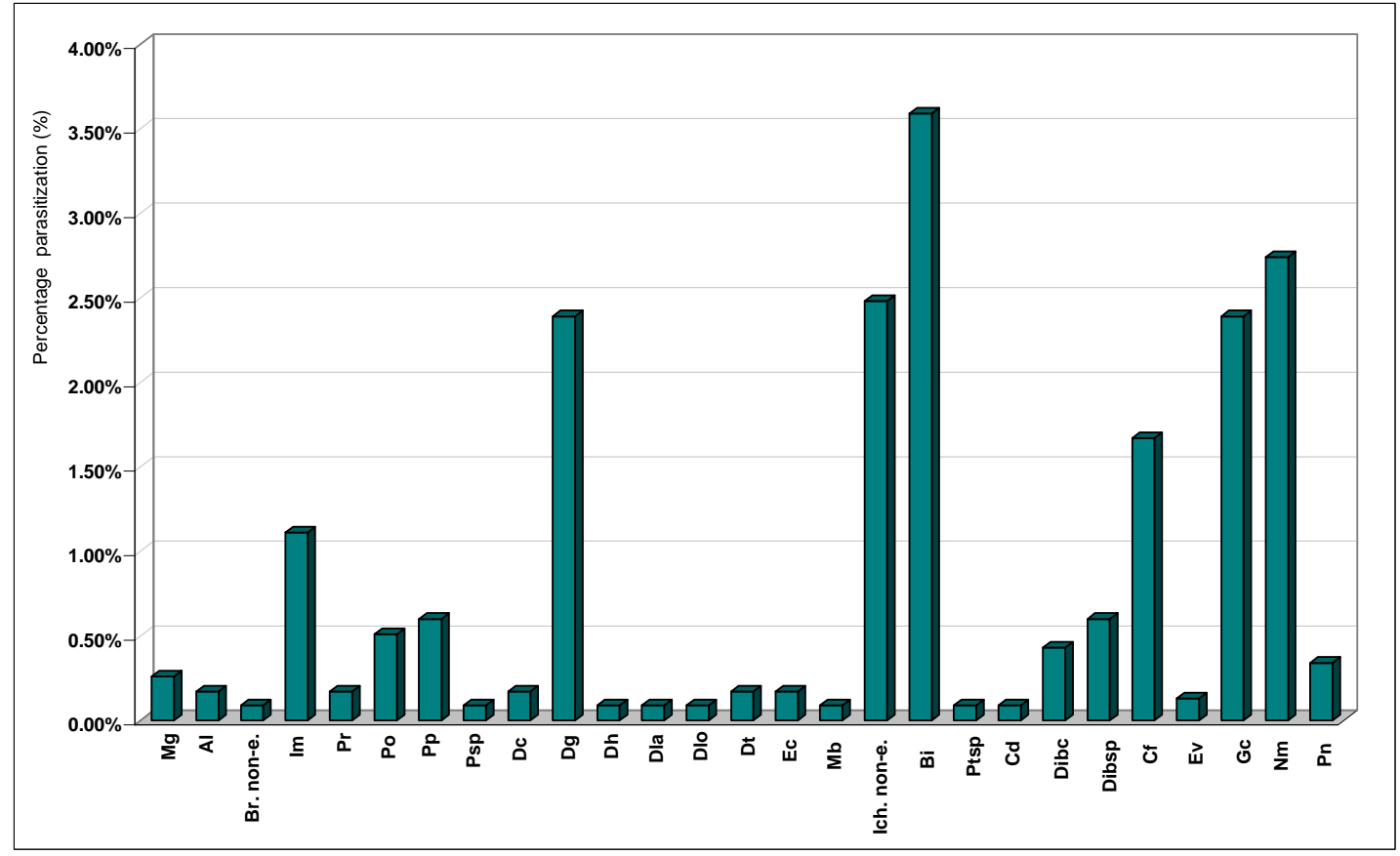

Figure 2. The importance of primary parasitoids in reducing of the Sparganothis pilleriana (Den. et Schiff.) populations in Southern vineyards

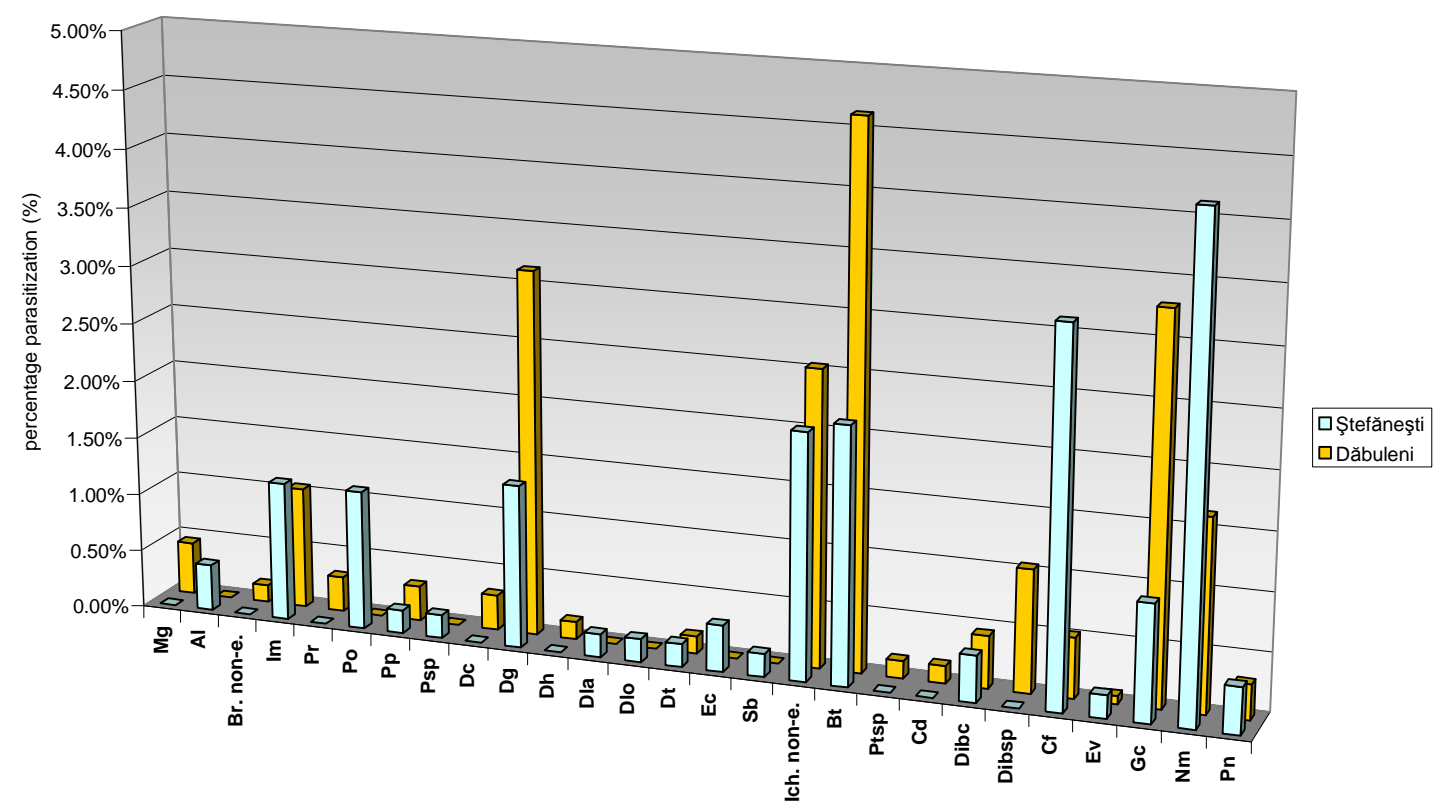

Figure 3. The importance of primary parasitoids in reducing of the Sparganothis pilleriana (Den. et Schiff.) populations in Ştefăneşti and Dăbuleni vineyards

$\mathrm{Al}$ - Apanteles lenea; $\mathrm{Bt}$ - Brachymeria tibialis; Br. non-e. - non-emerging Braconidae; Cd - Cyclogastrella deplanata;

Cf - Colpoclypeus florus; Dc - Diadegma contractum; Dibc - Dibrachys cavus; Dg - Diadegma germanicum; Dh -

Diadegma holopygum; Dla - Diadegma laricinellum; Dlo - Diadegma longicaudatum; Dt - Diadegma tenuipes; Dibsp

- Dibrachys spp.; Ec - Exochus consimilis; Ev - Elasmus viridiceps; Gc - Goniozus claripennis; Im - Itoplectis

maculator; Ich. non-e. - non-emerging Icheumonidae; Mg - Microgaster globata; Nm - Nemorilla maculosa; $\mathrm{Pi}-$

Pimpla rufipes; Po - Phytodietus ornatus; Pp - Phytodietus polyzonias; Psp - Phytodietus spp.; Ptsp - Pteromalus spp.;

$\mathrm{Pn}$ - Pseudoperichaeta nigrolineata; $\mathrm{Mb}$ - Mesochorus bilineatus 


\section{Current Trends in Natural Sciences}

Vol. 9, Issue 17, pp. 307-316, 2020

https://doi.org/10.47068/ctns.2020.v9i17.039

Current Trends in Natural Sciences (on-line)

ISSN: 2284-953X

Current Trends in Natural Sciences (CD-Rom)

ISSN: 2284-9521

ISSN-L: 2284-9521

ISSN-L: 2284-9521

Table 2. Efficiency of the family of primary parasitoids in reducing of the Sparganothis pilleriana populations

\begin{tabular}{|c|c|c|c|c|c|c|c|c|c|c|c|c|}
\hline \multicolumn{2}{|c|}{ Vineyard } & \multicolumn{6}{|c|}{ Ştefăneşti } & \multicolumn{4}{|c|}{ Dăbuleni } & \multirow{2}{*}{ Total } \\
\hline \multicolumn{2}{|c|}{ Year } & 1998 & 2000 & 2001 & 2002 & 2003 & Subtotal & 2000 & 2001 & 2002 & Subtotal & \\
\hline \multicolumn{2}{|c|}{ No. of ind. coll. } & 27 & 64 & 124 & 164 & 122 & 501 & 215 & 308 & 146 & 669 & 1170 \\
\hline \multicolumn{2}{|c|}{$\begin{array}{l}\text { No. of ind. par. } \\
\text { (No..i.p.) }\end{array}$} & 5 & 12 & 18 & 30 & 34 & 99 & 61 & 67 & 16 & 144 & 243 \\
\hline \multicolumn{2}{|l|}{$\%$} & 18.51 & 18.75 & 14.52 & 18.29 & 27.87 & 19.76 & 28.37 & 21.75 & 10.96 & 21.52 & 20.77 \\
\hline \multirow{2}{*}{$\begin{array}{l}\text { Ichneumoni- } \\
\text { dae }\end{array}$} & $\begin{array}{l}\text { No. spp./ } \\
\text { No. i.p. }\end{array}$ & $3 / 5$ & $2 / 5$ & $1 / 7$ & $5 / 12$ & $4 / 10$ & $10 / 39$ & $3 / 26$ & $5 / 25$ & $1 / 7$ & $7 / 58$ & $13 / 97$ \\
\hline & $\%$ & 18.51 & 7.81 & 5.65 & 7.32 & 8.20 & 7.78 & 12.09 & 8.12 & 4.79 & 8.67 & 8.29 \\
\hline \multirow[t]{2}{*}{ Braconidae } & $\begin{array}{l}\text { No. spp./ } \\
\text { No. i.p. }\end{array}$ & - & - & - & $1 / 2$ & - & $1 / 2$ & $1 / 1$ & $1 / 3$ & - & $1 / 4$ & $2 / 6$ \\
\hline & $\%$ & - & - & - & 1.22 & - & 0.4 & 0.47 & 0.97 & - & 0.6 & 0.51 \\
\hline \multirow{2}{*}{ Bethylidae } & $\begin{array}{l}\text { No. spp./ } \\
\text { No. i.p. }\end{array}$ & - & $1 / 1$ & $1 / 3$ & $1 / 1$ & - & $1 / 5$ & $1 / 5$ & $1 / 13$ & $1 / 4$ & $1 / 22$ & $1 / 27$ \\
\hline & $\%$ & - & 1.56 & 2.42 & 0.61 & - & 1.00 & 2.33 & 4.22 & 2.74 & 3.29 & 2.31 \\
\hline \multirow[t]{2}{*}{ Chalcididae } & $\begin{array}{l}\text { No. spp./ } \\
\text { No. i.p. }\end{array}$ & - & $1 / 1$ & $1 / 3$ & $1 / 6$ & $1 / 1$ & $1 / 11$ & $1 / 23$ & $1 / 8$ & - & $1 / 31$ & $1 / 42$ \\
\hline & $\%$ & - & 1.56 & 2.42 & 3.66 & 0.82 & 2.2 & 10.7 & 2.6 & - & 4.63 & 3.59 \\
\hline \multirow{2}{*}{$\begin{array}{l}\text { Pteromali- } \\
\text { dae }\end{array}$} & $\begin{array}{l}\text { No. spp./ } \\
\text { No. i.p. }\end{array}$ & - & - & $1 / 2$ & - & - & $1 / 2$ & - & $4 / 12$ & - & $4 / 12$ & $4 / 14$ \\
\hline & $\%$ & - & - & 1.61 & - & - & 0.4 & - & 3.9 & - & 1.79 & 1.2 \\
\hline \multirow{2}{*}{ Eulophidae } & $\begin{array}{l}\text { No. spp./ } \\
\text { No. i.p. }\end{array}$ & - & $1 / 3$ & $1 / 1$ & - & $1 / 12$ & $1 / 16$ & $1 / 3$ & - & $1 / 1^{*}$ & $1 / 4$ & $1 / 20$ \\
\hline & $\%$ & - & 4.69 & 0.81 & - & 9.84 & 3.19 & 1.4 & - & 0.69 & 0.52 & 1.7 \\
\hline \multirow{2}{*}{ Elasmidae } & $\begin{array}{l}\text { No. spp./ } \\
\text { No. i.p. }\end{array}$ & - & - & - & $1 / 1$ & - & $1 / 1$ & - & - & $1 / 1^{*}$ & $1 / 1$ & $1 / 2$ \\
\hline & $\%$ & - & - & - & 0.61 & - & 0.2 & - & - & 0.34 & 0.07 & 0.13 \\
\hline \multirow{2}{*}{ Tachinidae } & $\begin{array}{l}\text { No. spp./ } \\
\text { No. i.p. }\end{array}$ & - & $1 / 2$ & $1 / 2$ & $2 / 8$ & $2 / 11$ & $2 / 23$ & $1 / 3$ & $2 / 6$ & $2 / 4$ & $2 / 13$ & $2 / 36$ \\
\hline & $\%$ & - & 3.13 & 1.61 & 4.88 & 9.02 & 4.6 & 1.4 & 1.95 & 2.74 & 1.94 & 3.08 \\
\hline
\end{tabular}

* A case of multiple parasitism

Legend:

No. of ind. = number of collected larvae and pupae;

Ştef.= Ştefăneşti vineyard

No. of ind. par. (No. i.p.) = number of larvae and pupae parasitized;

Dăb.= Dăbuleni vineyard

No. spp. $=$ number of primary parasitoids species.

Thus, over the period 2000-2001, the number of species of primary parasitoids and hyperparasitoids was much higher in Dăbuleni (19), where a numerous host population was to be found, as compared to that in Ştefăneşti (10); there, the action of the populations was much more efficient, as illustrated by the parasitizing ratios of the primary parasitoids.

In 2002, the parasitizing ratio was dramatically reduced in Dăbuleni, on account of the fact that the insecticide treatment applied in June affects, once with the host species, its parasitoids as well, so all the parasitoids obtained were larval, D. germanicum (Horst.), G. claripennis (Först.), C. florus (Walk.), E. viridiceps Thoms., and larval-pupal, N. maculosa (Meig.) and P. nigrolineata (Walk.).

In Ştefăneşti, since the local conditions are favorable to the host, the parasitoids become more active, so that, in addition to the diversification of the number of species, an increase in the value of parasitism occurs. An increase in the pest population is found, which will be conducive to the augmentation of the host-primary parasitoid-hyperparasitoid relationships, from 6 in 2000 to 12 in 2002. After the year 2010, the interests of real estate developers from Ştefăneşti and the economic difficulties from Research - Development Center for Field Crops on Sandy Soils Dăbuleni, led to 
the loss of many vineyards, which affected the S. pilleriana (Den. Et Schiff.) populations, and implicitly host-parasitoid relationships.

The secondary parasitoids complex of Goniozus claripennis (Först.)

In France, Voukassovitch (1924) investigated the parasitoids of this host and obtained 6 species of calcidoids as secondary parasitoids: Pteromalus cupreus Nees, P. chrysos (Walk.), Cyclogastrella deplanata (Nees), Catolaccus ater (Ratzb.) (Pteromalidae), Eupelmus urozonus Dalm. (Eupelmidae), and Elasmus flabellatus (Fonsc.) (Elasmidae).

In our study, the rearing in laboratory have highlighted 4 species in the parasitoid complex of $G$. claripennis (Först.): C. ater (Ratzb.), Elasmus viridiceps Thoms., Elasmus spp., and Eupelmus vesicularis (Retz.) (Table 3).

C. ater (Ratzb.) was obtained as a pupal, solitary, secondary endoparasitoid in Dăbuleni/27.06.2000/10.07.2000/1ð and reduced the host population with 1.19\%. In Romania, this parazitoid was obtaind from Cotesia (=Apanteles) glomerata (L.) cocoons, in the parasitoid complex of Pieris brassicae (L.) (Andriescu, 1972-1973).

E. viridiceps Thoms. was obtained as a larval, solitary, secondary ectoparasitoid in Dăbuleni/9.05.2000/1ㅇ 5.07.2001/1ㅇ. In Romania, this parasitoid was obtained as primary parasitoid on the Rhopobota naevana (Hb.), Pandemis heparana (Den. et Schiff.), and Adoxophyes orana (Fisch. v Rösl.) larvae (Diaconu, 1999).

Table 3. Importance of secondary parasitoids in parasitizing of Goniozus claripennis (Först.) larvae

\begin{tabular}{|c|c|c|c|c|c|c|c|c|c|}
\hline \multirow{2}{*}{\multicolumn{2}{|c|}{$\frac{\text { Vineyard }}{\text { Year }}$}} & \multicolumn{4}{|c|}{ Dăbuleni } & \multicolumn{4}{|c|}{ Ştefăneşti } \\
\hline & & 2000 & 2001 & 2002 & Total & 2000 & 2001 & 2002 & Total \\
\hline \multicolumn{2}{|c|}{ No. of host larvae } & 18 & 57 & 9 & 84 & 2 & 10 & 2 & 14 \\
\hline \multicolumn{2}{|c|}{ No. of larvae parasitized } & 2 & 1 & 2 & 5 & 0 & 0 & 1 & 1 \\
\hline \multicolumn{2}{|c|}{$(\%)$} & 11.11 & 1.75 & 22.22 & 5.95 & 0 & 0 & 50.00 & 7.14 \\
\hline \multirow{2}{*}{$\begin{array}{c}\text { Catolaccus } \\
\text { ater }\end{array}$} & No. & 1 & - & - & 1 & - & - & - & - \\
\hline & $\%$ & 5.56 & - & - & 1.19 & - & - & - & - \\
\hline \multirow{2}{*}{$\begin{array}{c}\text { Elasmus } \\
\text { spp. }\end{array}$} & No. & - & - & 2 & 2 & - & - & - & - \\
\hline & $\%$ & - & - & 22.22 & 2.38 & - & - & - & - \\
\hline \multirow{2}{*}{$\begin{array}{c}\text { Elasmus } \\
\text { viridiceps }\end{array}$} & No. & 1 & 1 & - & 2 & - & - & - & - \\
\hline & $\%$ & 5.56 & 1.75 & - & 2.38 & - & - & - & - \\
\hline \multirow{2}{*}{$\begin{array}{l}\text { Eupelmus } \\
\text { vesicularis }\end{array}$} & No. & - & - & - & - & - & - & 1 & 1 \\
\hline & $\%$ & - & - & - & - & - & - & 50.00 & 7.14 \\
\hline
\end{tabular}

Elasmus spp. was obtained as a larval, solitary, secondary ectoparasitoid in Dăbuleni/27.05.2002/12.06.2002/1; 27.05.2002/13.06.2002/1 $\overbrace{}^{\text {. }}$.

E. vesicularis (Retz.) was obtained as a pupal, solitary, secondary endoparasitoid in Ştefăneşti/28.06.2002/19. In Romania, it was obtained from Macrocentrus pallipes (Nees) cocoons (Diaconu, 1999).

According to our observations, these parasitoids reduced the G. claripennis (Först.) populations with $6.12 \%$.

\section{CONCLUSIONS}

In the vineyards situated in southern Romania, the populations of $S$. pilleriana (Den. et Schiff.) are controlled by 29 species of primary parasitoids and hyperparasitoids, which ensure a $20.77 \%$ reduction of the host population. The species B. tibialis (Walk.), N. maculosa (Meig.), D. germanicum (Horst.) and G. claripennis (Först.) are prevalent. In point of family, the Ichneumonidae have the greatest contribution to the reduction of the pest. 
In Dăbuleni, a stable biocoenosis can be found up to the year 2002, characterized by a high number of species of parasitoids (19); subsequently, parasitism was drastically reduced thanks to chemical treatments. In Ştefăneşti, beginning with 2000, the favorable climate and the lack of chemical treatments determines an increase in the pest population, which will lead to an increase in the hostprimary parasitoid-hyperparasitoid relationships, i.e. from 6 in 2000 to 12 in 2002 . After the year 2010, a great part of the vineyards was removed, which led to affect the population of this pest, as the parasitoids species searched for alternative hosts.

Thirty-three new host-parasitoid relationships were established: 11 host-primary parasitoid relationships new to science and 12 relationships new for Romania, five primary parasitoidsecondary parasitoid relationships new to science, and five relationships new for Romania.

\section{ACKNOWLEDGEMENTS}

I wish to express my sincere thanks to dr. Aurel Lozan from Moldova State University, Chişinău (Moldova) who identified the Braconidae species, and to dr. Hans-Peter Tschörsnig from Staatliches Museum für Natürkunde - Stuttgart (Germania) who identified the Tachinidae species. Professor dr. Constantin Pisică (†) from „Al. I. Cuza” University, Iaşi (Romania) identified the Ichneumonidae species. I also offer my thanks to dr. Rățoi Iulian from Research- Development Center for Field Crops on Sandy Soils Dăbuleni for the aid provided.

\section{REFERENCES}

Alfaro Moreno, A. (1966). Pequenos ensayos de lucha contra la piral de la vid. [A few attempts to control of the vine Pyrala]. Boln.Patol. veg. Ent. Agric. 29, 45-58.

Andriescu, I. (1972 - 1973). Chalcidoidiens (Chalcidoidea, Hym., Insecta) d'importance economique de Roumanie. (Catalogue hôte/parasite, parasite/hôte). [Chalcidoidiens (Chalcidoidea, Hym., Insecta) of economic importance in Romania. Host / parasite, parasite / host catalog]. Lucr. Staț. "Stejarul" Pîngăraţi (Roumanie). V, 155-190.

Bărbuceanu, D. (2005). Sparganothis pilleriana Den. et Schiff. (Lepidoptera: Tortricidae) - a potential pest in the vineyards of Southern Romania. Teze ale Conferinței Ştiinţifice Internaţionale "Aspecte inovative în viticultură şi vinificație". Chişinău, 76-81.

Bărbuceanu, D., Andriescu, I. (2010). Colpoclypeus florus (Walker) (Hymenoptera: Eulophidae), an important parasitoid of grape leaf-roller Sparganothis pilleriana (Lep.: Tortricidae) in Southern vineyards of Romania. Oltenia. Studii şi Comunicări. Ştiințele Naturii. 26, 119-123.

Bărbuceanu, D., Andriescu, I. (2012). Brachymeria tibialis (Walker) (Hymenoptera:Chalcididae) an important parasitoid of the pupae of Sparganothis pilleriana in the vineyards of Southern Romania. Analele Ştiințifice ale Univ. “Al.I.Cuza” Iaşi, seria Biologie animală. LVIII, 85-92.

Bovey, P. (1966). Super-familie des Tortricoides. In Balachowsky, A.S., Entomologie Appliquee a l'Agriculture. Tom II: Lepidopteres [Superfamily of the Tortricoides. In Balachowsky, A.S., Applied Entomology to Agriculture. Tom II: Lepidoptera]. (1, pp. 859-887). Paris: Eds. Masson \& C-ie, Paris.

Desneux, N., Decourtye, A., Delpuech, J.M. (2007). The sublethal effects of pesticides on beneficial arthropods. Annu Rev Entomol. 52,81-106. Retrieved January 23, 2020 from https://doi.org/10.1146/annurev.ento.52.110405.091440

Diaconu, A. (1999). Contribuţii la studiul complexelor parazitoide la tortricoide (Insecta: Lepidoptera, Tortricidae) dăunătoare în livezi [Contributions to the study of parasitoids complexes of tortricoides (Insecta: Lepidoptera, Tortricidae) which damage in the orchards]. PhD Thesis. Iaşi: „Al. I. Cuza” University, Faculty of Biology.

Galet, P. (1982). Les maladies et les parasites de la vigne. [Vine diseases and pests].Tome II, 1473-1519. Montpellier.

Geiger, F., Bengtsson, J., Berendse, F., Weisser, W.W., Emmerson, M., Morales, M.B., Onate, J.J., Eggers, S., Pärt, T., Bommarco, R., Bengtsson, L., Clement, L.W., Weisser, W.W., Olszewski, A., Ceryngier, P., Hawro, V., Inchausti, P., Fischer, C., Flohre, A., Thies, C., Tscharntke, T. (2010). Persistent negative effects of pesticides on biodiversity and biological control potential on European farmland. Basic Appl Ecol. 11, 97- 105. Retrieved March 17, 2020 from https://doi.org/10.1016/j.baae.2009.12.001

Luca, N. (1981). Contribuții la studiul sistematic: biologie, ecologie şi combaterea lepidopterelor dăunătoare la cultura viței de vie în podgoria Bucium-Iaşi. [Contributions to the systematic study: biology, ecology and control of harmful lepidopterans to the vine in the Bucium-Iaşi vineyard]. PhD Thesis. Iaşi: Faculty of Agriculture. 


\section{Current Trends in Natural Sciences}

Vol. 9, Issue 17, pp. 307-316, 2020

https://doi.org/10.47068/ctns.2020.v9i17.039

Current Trends in Natural Sciences (on-line)

ISSN: 2284-953X

Current Trends in Natural Sciences (CD-Rom)

ISSN: 2284-9521

ISSN-L: 2284-9521

ISSN-L: 2284-9521

Martinez, M. (2012). Clé d'identification des familles, genres et/ou espèces de diptères auxiliaires, parasitoïdes ou prédateurs des principaux insectes nuisibles à la vigne. In: Sentenac, G. (Ed.), La faune auxiliaire des vignobles de France. [Identification key of the families, genera and / or species of auxiliary diptera, parasitoids or predators of the main insects harmful to the vine. In: Sentenac, G. (Ed.) The auxiliary fauna of the vineyards in France]. (pp. 315-320). Paris: Edition France Agricole, Paris.

Moreau, J., Villemant, C., Benrey, B., Thiéry, D. (2010). Species diversity and composition of larval parasitoids of the European grapevine moth (Lobesia botrana): the influence of region and cultivar. Biol Control. 54, $300-306$. Retrieved March 17, 2020 from https://doi.org/10.1016/j.biocontrol.2010.05.019

Paull, C., Austin, A. D. (2007). The hymenopteran parasitoids of light brown apple moth, Epiphyas postvittana (Walker) (Lepidoptera: Tortricidae) in Australia. Aust J Entomol. 45(2006), 142-156. Retrieved January 15, 2020 from https://doi.org/10.1111/j.1440-6055

Pisică, C. (2005). List of Ichneumonids (Hymenoptera, Ichneumonoidea) from Romania. Studii şi Comunicări, Compl. Muz. Şt. Nat. "Ion Borcea”. 20, 135-157.

Predescu, S. (1967). Contribuții la studiul bioecologiei piralei viței de vie, Sparganothis pilleriana Schiff. [Contributions to the study of the bioecology of the vine pyrala, Sparganothis pilleriana Schiff.]. Lucr.Ştiinț. ser. Agron., Timişoara. 10, 629-636.

Predescu, S. (1971). Studiul biologiei, ecologiei şi a metodelor de combatere a insectei "Sparganothis pilleriana Den. et Schiff." [Study of the biology, ecology and methods of control of the insect "Sparganothis pilleriana Den. et Schiff."]. PhD Thesis. Bucureşti: Faculty of Agronomy.

Pykhova, V.T. (1968). The control of the grape moths. Zashchita Rastenii. 13 (11), 48-49.

Reineke, A., Thiéry, D. (2016). Grapevine insect pests and their natural enemies in the age of global warming. Journal of Pest Science. 89, 313-328.

Russ, K. (1969). Beitrage um Territorialverhalten der Raupen des Springwurmwicklers (Sparganothis pilleriana Schiff.). [Contributions to territorial behavior of the grape leaf-roller Sparganothis pilleriana Schiff.]. Planzenschutzberichte. 40 (1/2), 1-9.

Saglio, P., Priesner, E., Descoins, C., Gallois, M. (1977). A synthetic attractant for the grape pyralid Sparganothis pilleriana (Schiffermüller). C. R. Hebd. Seances Acad. Sci., Ser. D Sci. Nat. 284(20), 2007-2010.

Schirra, K.J., Louis, F. (1995). Auftreten von naturlichen Antagonisten des Springwurmwicklers Sparganothis pilleriana. [About natural enemies of the grape leaf-roller Sparganothis pilleriana]. Pfalz. Deutsches WeinbauJahrbuch. 46, 129-140.

Thiéry, D., Xuereb, A., Villemant, C., Sentenac, G., Delbac, L., Kuntzman, P. (2001). Les parasites de tordeuses de vignobles : aperçu de quelques espèces présentes dans 3 régions viticoles françaises. [Parasitoids of tortricoides from vineyard: overview of some species present in 3 French wine regions]. Integrated Control in Viticulture IOBC/ wprs Bulletin. 24 (7), $135-141$.

Thiéry, D. (2008). Les tordeuses nuisibles à la vigne. In 'Les ravageurs de la vigne'. [The harmful tortricoides in the vineyards. In 'The pests of the vine']. Féret, Bordeaux, 1-54.

Thiéry, D., Delbac, L., Xuereb, A., Villemant, C., Moreau, J. (2011). Control of grape berry moth larvae using parasitoids: should it be developed?. Integrated Protection and Production in Viticulture IOBC/ wprs Bulletin. 67, $189-196$.

Thompson, W.R. (1957). A catalogue of the Parasites and Predators of Insects Pests, Section 2, Host Parasite Catalogue. Part 4, Host of the Hymenoptera (Ichneumonidae). Published by Commonwealth Inst. Bio.Control. Ottawa, pp 561.

Voukassovitch, P. (1924). Contribution a l'etude de l'Eudemis (Polycrosis botrana Schiff), de la Pyrale de la Vigne (Enophthira pilleriana Schiff.) et de leurs parasites. [Contribution to the study of Eudemis (Polycrosis botrana Schiff), the European vine moth (Oenophthira pilleriana Schiff.) and their parasites]. PhD Thesis. Toulouse. Libr. Marqueste.

Villemant, C., Delvare, G., Martinez, M., Sentenac, G., Kuntzmann, P. (2012). Parasitoïdes de tordeuses. In: Sentenac G. (Ed.) La faune auxiliaire des vignobles de France [Parasitoids of tortricoides. In: Sentenac G. (Ed.), Auxiliary fauna of the vineyards in France]. (pp. 119-140). Paris: Editions France Agricole, Paris.

Zoebelein, G. (1966). Problems of the control of injurious insects in agriculture in Iran. Anzeiger für Schädlingskunde. 39(1), 3-8.

https://fauna-eu.org/, Retrieved January 25, 2020 